\title{
ДО ПИТАННЯ ПРО ЗАРУБІЖНИЙ ДОСВІД ОРГАНІЗАЦІЇ ПРОТИДІЇ МІЖНАРОДНОМУ ТЕРОРИЗМУ
}

Конопельський В. Я.

Нові тенденції у розвитку міжнародного тероризму створюють додаткові виклики для національної і міжнародної безпеки і потребують належного реагування. 3 огляду на це заходи з удосконалення антитерористичної політики i боротьби з тероризмом як на національному, так $і$ на міжнародному рівні повинні мати перманентний характер навіть за умов низького рівня відповідної загрози. Наразі зусилля багатьох країн спрямовані на посилення захисту від терористичної загрози. Аналіз антитерористичної діяльності міжнародних і регіональних організацій, а також державної політики низки країн світу дозволяє виокремити актуальні тенденції протидії тероризму.

Досліджено актуальні тенденції у розвитку міжнародного тероризму, особливості боротьби з тероризмом у сучасному світі, трансформацію характеру терористичної загрози в Україні, механізм забезпечення стійкості держави до такої загрози. Проведено аналіз норм законодавства США, Великобританії, ФРН, Франції.

Наводяться основні напрями протидіі тероризму на сучасному етапі. Формулюються пропозиції про нові форми протидіі зазначеному явищу як на законодавчому рівні, так і на практиці.

Ключові слова: тероризм, протидія, контртерористична діяльність, світова спільнота, конвенція.

Новые тенденции в развитии международного терроризма создают дополнительные вызовы для национальной и международной безопасности и требуют надлежащего реагирования. Из-за этого меры по совершенствованию антитеррористической политики и борьбы с терроризмом как на национальном, так и на международном уровне должны иметь перманентный характер даже в условиях низкого уровня соответствующей угрозы. Сейчас усилия многих стран направлены на усиление защиты от террористической угрозы. Анализ антитеррористической деятельности международных и региональных организаций, а также государственной политики ряда стран мира позволяет выделить актуальные тенденции противодействия терроризму.

Исследованы актуальные тенденции в развитии международного терроризма, особенности борьбы с терроризмом в современном мире, трансформация характера террористической угрозы в Украине, механизм обеспечения устойчивости государства к такой угрозе. Проведен ана лиз норм законодательства США, Великобритании, ФРГ, Франции.

Приводятся основные направления противодействия терроризму на современном этапе. Формулируются предложения о новых формах противодействия указанному явлению как на законодательном уровне, так и на практике.

Ключевые слова: терроризм, противодействие, контртеррористическая деятельность, мировое сообщество, конвенция.

Terrorism in all their forms pose a huge threat to the humanity. This very dangerous modern phenomena entail such negative factors as military provocations and ethnic hatred. It also spread

Конопельський В. Я., 2019 fear and mistrust between social groups countering terrorism is complicated by the fact that they are difficult to predict, so it's not always possible to talk about their timely prevention.

Today, no country in the world can say with certainty that it's "free" from the problems related to the threat of terrorism. These terrible social phenomena have put down their root deeply. They have acquired a global character, covering the entire international community. In such circumstances the problems of improving the mechanisms to counter international extremism and terrorism, including the legislative level, are of particular importance. The purpose of the article is to analyze the issues related to the development of the main directions of international counteraction. The use of foreign experience of legal regulation of combating terrorism by creating legislative "barrier" ensuring the protection of citizens' life and health, rights, freedoms and interests is also explored. International regulations determining the legal means of combating the crimes of terrorist nature are listed and analyzed. The main area of combating terrorism at the present stage are described. The proposals for new forms of countering these phenomena both at the legislative level and in practice are formulated.

Emerging trends in the development of international terrorism create additional challenges for national and international security and require proper response. Against this background, measures to improve counter-terrorism policies and counter-terrorism, both nationally and internationally, must be permanent, even in the face of a low level of appropriate threat. Many countries are currently working to strengthen their defense against the terrorist threat. The analysis of the anti-terrorist activities of international and regional organizations, as well as the state policy of several countries of the world, allows us to identify current trends in counter-terrorism.

The current trends in the development of international terrorism, the features of the fight against terrorism in the modern world, the transformation of the nature of the terrorist threat in Ukraine, the mechanism of ensuring the stability of the state to such a threat are investigated. The analysis of norms of legislation of the USA, Great Britain, Germany, France is carried out.

The main directions of counteraction to terrorism are presented at the present stage. Suggestions about new forms of counteraction to this phenomenon are formulated both at the legislative level and in practice.

Key words: terrorism, counteraction, international community, counter terrorism activities, convention.

Постановка проблеми та їі актуальність. Сьогодні про жодну державу в світі не можна зі впевненістю сказати, що вона вільна від проблем, пов'язаних з загрозою тероризму. Це складне соціальне явище глибоко пустило своє коріння та досягло мегамасштабів, охопило всю світову спільноту.

До XIX століття включно більшість терористичних актів, а серед них було немало таких, що увійшли в історію, вчинялась на території конкретної держави. У XX столітті значна кількість соціально-політичних та історичних процесів була сфокусована навколо протистояння капіталізму та соціалізму. Кожна сторона для досягнення своїх цілей досить часто застосовувала 
методи терору. За таких умов тероризм став міжнародним геополітичним явищем.

3 розпадом СРСР та закінченням «холодної війни» в Європі носієм стратегії тероризму стали радикальні ісламські рухи, які виникли як імперіалістичні в процесі звільнення країн Латинської Америки, Азії, Африки від колоніальної залежності, потім трансформувалися в боротьбу за владу всередині країн, що звільнилися, а наприкінці XX - поч. XXI ст. набули розповсюдження в усьому світі. Саме в цей час міжнародний тероризм став головною геополітичною загрозою сучасності, оскільки його мережеві структури охоплюють майже всі держави, він набуває ідеологічно стійкого характеру боротьби правовірних з невірними.

3 огляду на це найбільш актуальними та першочерговими стають задачі вдосконалення основних напрямів міжнародної протидії, а також використання зарубіжного досвіду правового регулювання протидії зазначеному негативному соціальному явищу сучасності шляхом побудови законодавчого бар'єру, що виконував би функції захисту життя та здоров'я громадян, їх прав, свобод і інтересів.

Аналіз останніх досліджень і публікацій. У різні роки до проблем дослідження тероризму в своїх наукових працях зверталися такі зарубіжні вчені, як Р. Хантер, Р. Бейснер, С. Гук, М. Келдор, А. Конте, Г. Аллісон, Р. Фірі, П. Девіс, Б. Дженкінс, А. Шейлі, Дж. Белл, ч. Добсон. Серед вітчизняних вчених дану тему досліджували Д. Нікіфорчук, М. Руденко, Б. Канцелярук, В. Ємельянов, Ю. Іванов, С. Моханчук, О. Сушко, Г. Токаревський.

Правову основу протидії тероризму в Україні складають Конституція України, Кримінальний кодекс України, Закон України «Про боротьбу з тероризмом», Європейська конвенція про боротьбу з тероризмом 1977 року, Міжнародна конвенція про боротьбу з бомбовим тероризмом 1997 року, Міжнародна конвенція про боротьбу з фінансуванням тероризму 1999 року. Однак, на нашу думку, попри достатнє нормативно-правове регулювання, залишаються відкритими певні питання щодо протидії тероризму, зокрема перелік конкретних заходів, спрямованих на попередження, захист та ліквідацію наслідків тероризму.

Метою статті $\epsilon$ аналіз зарубіжного досвіду організації протидії міжнародному тероризму.

Виклад основного матеріалу. Слова «терор» та «тероризм» в перекладі з латини означають «страх», «жах». Однак дослівний переклад розкриває не саме поняття терору, а лише його прямий наслідок на емоційному рівні. 3 часом в означене поняття почало вкладатися не тільки значення прямого насильства, але і сам процес, який викликає цей страх та жах.

У сучасній юриспруденції існує багато наукових думок, трактовок та визначень поняття «тероризм», кожна з яких має право на існування. Слід зауважити, що такі визначення, доповнюючи одне одного, означають найбільш небезпечні форми виявлення протиправної діяльності особи чи групи осіб, об'єднаних у злочинні угруповання та організації з метою спричинення шкоди людині, суспільству і державі, що несуть ідеологію ненависті, страху та нетерпимості.

Саме тому держави у всьому світі активно протидіють різним проявам терористичної діяльності та не визнають тероризм засобом для досягнення політич- них цілей. Головний напрям в цій діяльності - створення нормативно-правової бази з протидії тероризму, яка найбільш активно проявилась в Європі після Другої світової війни.

Так, у низці країн були прийняті нормативні акти, які на законодавчому рівні закріпили заборону фашизму у будь-яких його проявах. Зокрема, були прийняті спеціальні документи, що забороняли діяльність профашистських та пронацистських організацій (наприклад, австрійський конституційний закон «Про заборону Націонал-соціалістичної робочої партії Німеччини» (1945р.), італійський закон «Про заборону неофашистської діяльності» (1952 р.), португальський закон «Про заборону фашистських організацій» (1978р.)), розроблені міжнародні стандарти, спрямовані проти зловживань свободою слова, інформацією, висловленням своєї думки.

Протидія тероризму в різних проявах на міждержавному рівні представлена такими міжнародно-правовими документами: Конвенцією про злочини і деякі інші акти, що вчиняються на борту повітряних суден (1963 р., Токіо); Конвенцією про боротьбу з незаконним захопленням повітряних суден (1970р., Гаага); Конвенцією про боротьбу з незаконними актами, спрямованими проти безпеки цивільної авіації (1971 р., Монреаль); Конвенцією про попередження і покарання злочинів проти осіб, що користуються міжнародним захистом, у тому числі дипломатичних агентів (1973 р., Нью-Йорк); Міжнародною конвенцією про боротьбу з захопленням заручників (1979 р., Нью-Йорк; Конвенцією про боротьбу з незаконними актами, спрямованими проти морського судноплавства (1988 р., Рим); Міжнародною конвенцією про боротьбу з бомбовим тероризмом (1997 р., Нью-Йорк); Міжнародною конвенцією про боротьбу з фінансуванням тероризму (1999р.); Шанхайською конвенцією про боротьбу з тероризмом, сепаратизмом та екстремізмом (2001р.); Міжнародною конвенцією зі знищення всіх форм расової дискримінації (1965р.). Ці документи свідчать про те, що тероризм, сепаратизм та екстремізм незалежно від їх мотивів не можуть бути виправдані за жодних обставин, а особи, винні у вчиненні таких діянь, повинні бути притягнені до відповідальності відповідно до закону. У більшості зарубіжних країн на законодавчому рівні заборонені расистські виступи, а також провокаційні заяви, що висловлюють ненависть і зневагу до людей на підставі їх расової чи етнічної належності, національності та віросповідання.

В умовах зростання активності терористичних організацій і угруповань в різних регіонах світу, збільшення кількості проявів насильства та погроз вчинення терористичних актів щодо мирних громадян, важливих стратегічних об'єктів і навіть дипломатичних місій органи державної влади багатьох країн послідовно розробляють систему заходів протидії цьому явищу. Основними iї напрямами $\epsilon$ такі: удосконалення нормативно-правової бази, вдосконалення діяльності спеціальних служб, посилення боротьби з фінансуванням тероризму, а також активізація роз'яснювальної й ідеологічної роботи.

3 метою підвищення ефективності боротьби з міжнародними терористичними організаціями і координації діяльності різних відомств у цьому напрямі були розроблені документи, що постійно оновлюються, з переліком організацій, юридичних і фізичних осіб, які здійснюють терористичну діяльність або надають підтримку такій діяльності. 
У США політика щодо міжнародного тероризму має такі принципи: жодних поступок терористам; тиск на країни, які підтримують тероризм; використання повною мірою легальних механізмів покарання міжнародних терористів; надання допомоги в цій сфері іншим країнам.

У США з 1958 року було прийнято декілька десятків законів і підзаконних актів, що стосуються боротьби з тероризмом. Найбільш важливими серед них $€$ Таємна Виконавча директива Президента № 39 (червень 1995 року), Закон «Про боротьбу з тероризмом і застосування смертної кари» (квітень 1996 року), Виконавча директива президента № 62 (травень 1998 року), Закон «Про надання додаткових повноважень спецслужбам в сфері боротьби з тероризмом» (жовтень 2001 року). Вказані законодавчі акти значно розширили права федерального керівництва, правоохоронних органів і адміністрації штатів з виявлення і попередження терористичних актів, що готуються як на території США, так і за кордоном. Вони визначили новий, більш системний підхід до протидії тероризму в XXI столітті.

Спостерігається корегування чинного законодавства в напрямі створення сприятливих умов для антитерористичної боротьби, посилення кримінальних покарань за терористичну діяльність і в країнах Західної Європи.

Після відомих подій в США у вересні 2001 року влада Великобританії в терміновому порядку переглянула положення закону «Про тероризм» у контексті розширення функцій спеціальних служб. Спеціальні та правоохоронні органи отримали додаткові повноваження у протидії екстремістським угрупованням. Поліції були надані додаткові права арештовувати і допитувати осіб за підозрою в їх причетності до терористичної діяльності. Був розширений список організацій, діяльність яких на території країни стала забороненою, за рахунок включення до нього низки північноірландських i ісламістських угруповань. Влада здійснила низку інших заходів.

Бундестагом ФРН були прийняті поправки до антитерористичного законодавства, спрямовані на розширення повноважень імміграційних служб МВС з висилання за межі країни небажаних іноземців.

Національна асамблея Французької Республіки в жовтні 2001 року погодила запропоновані президентом і урядом додаткові заходи з забезпечення державної безпеки, які значно розширили повноваження спецслужб з перевірки сигналів про можливість вчинення терористичних актів. У цій країні були введені обмеження прав особи, зокрема на свободу пересування та вибір місця проживання. Поліція отримала право оглядати підозрілі автомобілі і проводити особистий обшук громадян без судового рішення, керуючись лише підозрою в їх причетності до терористичної діяльності.

Однак можемо констатувати певну недостатність та недосконалість наведених заходів, про що свідчать останні терористичні акти, що відбулися і в Німеччині, i у Франції, і у Великобританії. Проте робота в напрямку тісної співпраці та координації між правоохоронними органами країн Європейського Союзу у боротьбі з тероризмом, як уявляється, жодним чином не припиняється, оскількив рамках Євросоюзубуластворенаідієспеціальна структура для боротьби з тероризмом в країнах Європи.

Зоглядунацесуттєвароль, нанашудумку, повиннавідводитись зусиллям зі здійснення практичних заходів протидії таким злочинам. Ці заходи можна представити так.
1. Удосконалення професійної та організаційно-управлінської підготовки кадрів, що залучаються до контртерористичної діяльності, зокрема парламентаріїв, співробітників правоохоронних органів, судової і пенітенціарної систем, криміналістів, юристів тощо.

Вдосконалення світовою спільнотою професійної та організаційно-управлінської підготовки кадрів, задіяних у контртерористичній діяльності, вже відбувається. Так, в ході організованої в посольстві Великобританії зустрічі послів країн-учасниць глобального контртерористичного форуму представники США та Великобританії проінформували про реалізацію ініціативи зі створення на Мальті міжнародного інституту юстиції і верховенства права. На зустрічі було оголошено, що заснування даного інституту вступає в завершальну стадію. Головною метою його заснування $\epsilon$ не лише вдосконалення професійної підготовки кадрів, які 6 здійснювали контртерористичну протидію, але і обмін досвідом в антитерористичній сфері за рахунок налагодження активних контактів між провідними спеціалістами різних країн у даній галузі.

Передбачається, що аудиторією даного інституту будуть переважно представники Північної і Східної Африки, Близького Сходу з основним акцентом на так звані перехідні держави. Однак інститут готовий приймати слухачів з інших регіонів. Мається на увазі, що кожен курс буде формуватися на індивідуальній основі залежно від країни, для якої він призначений. Викладачі будуть набиратися з числа провідних експертів (криміналістів, суддів, юристів) як на довгостроковій основі, так і шляхом разових запрошень для викладання. Були визначені керівні органи інституту, зокрема міжнародна керівна рада, до якої входять Мальта як сторона, що приймає, ООН, Європейський Союз, Африканський Союз, а також як спостерігачі інші багатосторонні організації відповідного профілю.

2. Відкриття нових експертних майданчиків для впровадження передових кримінальних та процесуальних стандартів в систему антитерористичного правосуддя країн з так званою високою терористичною активністю.

Восени 2013 року під егідою контртерористичних структур ООН в Нью-Йорку був відкритий новий експертний майданчик для впровадження провідних кримінальних та процесуальних стандартів у систему антитерористичного правосуддя країн з так званою високою терористичною активністю.

Управління з наркотиків та злочинності ООН і контртерористичний виконавчий директорат $\mathrm{OOH}$ представили в Женеві Глобальну ініціативу з підвищення ефективності кримінального переслідування терористів.

На першому етапі проєкт мав на меті надати підтримку країнам Магрибу (група таких арабських країн: Марокко, Алжир, Лівія, Туніс, Західна Сахара, Мавританія) у приведенні їх правових систем у відповідність до провідних стандартів.

Надалі планується розширити географію проєкту, сфокусувавшись на південно-азіатському, африканському та близькосхідному напрямах. Західні експерти на конкретних прикладах виклали свої підходи до розслідування терактів, здійснення судочинства, розвитку взаємодії в даній сфері з іншими країнами. Доповідачі звертали увагу на певну затримку впровадження в країнах, що розвиваються, зафіксованих в документах 
ООН, Ради Європи і глобального контртерористичного форуму принципів і рекомендацій, а також труднощі при здійсненні міжнародної співпраці (в тому числі з питань екстрадиції і правової допомоги). Одним із корисних підсумків форуму слід назвати складений спільний список найбільш поширених проблем, з якими стикається державне обвинувачення при розкритті злочинів терористичної спрямованості.

3. Протидія поповненню лав бойовиків особами з числа мирного населення.

Одним з найважливіших напрямів міжнародної протидії тероризму $\epsilon$ діяльність європейських правоохоронних структур, спрямована на недопущення роботи з залучення громадян до лав бойовиків, а також недопущення створення мережі терористичних угруповань і вчинення ними терористичних актів.

Найбільш важливим показником такої роботи $\epsilon$ зменшення кількості осіб, що бажають виїхати до Сирії та інших країн, які втягнені до збройних конфліктів. Після виявлення потенційних кандидатів місцеві органи влади і громадські організації вживають заходів щодо їх переконання у недоцільності вступу до лав бойовиків, використовуючи для цього залучення членів родини та інші дії, наприклад, вилучення паспортів, позбавлення соціальних пільг тощо.

Окрім наведеного, застосовуються також форми і способи протидії в інформаційні сфері, наприклад, контрпропаганда ісламізму, блокування інтернет-ресурсів, що використовуються для вербування, а також поширення альтернативних пропозицій, зокрема й участі в діяльності різних гуманітарних проєктів.

Висновки. На підставі викладеного вище доходимо висновку, що основними напрямами протидії тероризму на сучасному етапі $\epsilon$ такі: створення міжнародної правової бази як найважливішої умови для здійснення скоординованих і результативних антитерористичних дій; формування міжнародних антитерористичних центрів для боротьби з тероризмом; активізація роботи, яка перешкоджає процесу вербування мирного населення до лав бойовиків; відкриття нових експертних майданчиків для впровадження провідних кримінальних і процесуальних стандартів в систему антитерористичного правосуддя країн, що мають високі показники терористичної активності.

На нашу думку, форми та способи боротьби з тероризмом необхідно розвивати і вдосконалювати. Міжнародна спільнота не повинна задовольнятися напрацьованими методами протидії зазначеним соціальним проявам. Вважаємо дуже важливим продовження роботи у сфері вдосконалення законодавства у контексті міжнародної протидії тероризму на сучасному етапі. Ця робота передбачає такі напрями:

1) укладення міжнародних договорів про створення загальноєвропейської системи збирання даних про авіапасажирів, покликаної підвищити ефективність боротьби з міжнародним тероризмом та організованою злочинністю;

2) складання єдиної нормативно-правової бази, спрямованої на розширення співпраці слідчих і судових органів для розшуку підозрюваних в тероризмі, їх кримінального переслідування та прийняття процесуальних рішень, що буде сприяти обміну інформацією в рамках міжнародної антитерористичної діяльності США, Європейського Союзу та держав Північної Африки та Близького Сходу;

3) розробку законопроєктів про обов'язкове встановлення адміністративного нагляду за громадянами, які були засуджені за злочини терористичної спрямованості та звільнилися з місць позбавлення волі. У рамках таких проєктів має передбачатися посилення кримінальної відповідальності за правопорушення даного виду та поширення радикальних ідеологій, зокрема і за допомогою застосування новітніх технологій;

4) своєчасне включення в списки зарубіжних терористичних організацій різноманітних радикальних сект та угруповань;

5) удосконалення професійної та організаційно-управлінської підготовки кадрів, що залучаються до контртерористичної діяльності, зокрема парламентаріїв, співробітників правоохоронних органів, судової і пенітенціарної систем, криміналістів, юристів тощо.

Ми вважаємо, що робота у зазначених напрямах дозволить проводити більш ефективну боротьбу з тероризмом на сучасному етапі розвитку міжнародно-правових відносин.

\section{Література}

1. Большой энциклопедический словарь. Москва : АСТ ; Астрель, 2003. 1248 с.

2. Вонсович О.С. Терористичні акти в Брюсселі як прояв недосконалості системи європейської безпеки. Гілея : науковий вісник. 2016. Вип. 108. С. 286-289.

3. Криворучко І.О. Вдосконалення кримінально-правової протидії терористичній діяльності з урахуванням світового досвіду. Часопис Київського університету права. 2016. № 4. С. 343-348.

4. Чуваков О.А. Міжнародне співробітництво у сфері боротьби зі злочинами терористичної спрямованості. Правова держава. 2010. № 12. С. 276-281.

5. ПаславськийІ. Терористичні акти у Норвегіїта особливості їх медійного висвітлення. Вісник Львівського універcumemy. Серія «Журналістика». 2015. Вип. 40. С. 258-270.

6. Ахтирська Н.М. Міжнародні стандарти та співробітництво в кримінальному провадженні щодо терористичної діяльності. Науковий вісник Ужгородського національного університету. Серія «Право». 2014. Вип. 28 (3). С. 52-55.

7. Требин М.П. Терроризм в XXI веке. Мн.: Харвест, 2004. 816 c.

8. Кожушко Е.П. Современный терроризм: анализ основных направлений / под общ. ред. А.Е. Тараса. Мн.: Харвест, 2000. 448 с.

9. Дикаев С.У. Террор, терроризм и преступления террористического характера. Санкт-Петербург : Юрид. Центр Пресс, 2006. 464 с.

10. Терроризм: борьба и проблемы противодействия : учеб. пособие для студентов юрид. вузов / под ред. В.Я. Кикотя, Н.Д. Эриашвили. Москва : Юнити, 2004. 592 с.

Конопельський В. Я., доктор юридичних наук, доцент, професор кафедри кримінального права та кримінології Одеського державного університету внутрішніх справ 